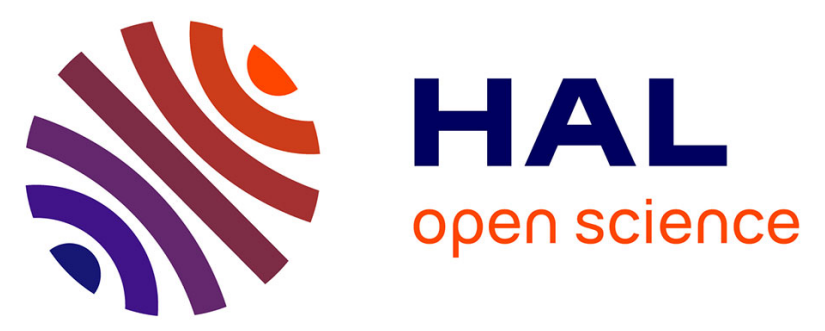

\title{
Raman and FTIR spectroscopy applied to the conservation report of paleontological collections: identification of Raman and FTIR signatures of several iron sulfate species such as ferrinatrite and sideronatrite
}

Véronique Rouchon, Hugues Badet, Oulfa Belhadj, Olivier Bonnerot, Bertrand Lavédrine, Jean-Guy Michard, Serge Miska

\section{To cite this version:}

Véronique Rouchon, Hugues Badet, Oulfa Belhadj, Olivier Bonnerot, Bertrand Lavédrine, et al.. Raman and FTIR spectroscopy applied to the conservation report of paleontological collections: identification of Raman and FTIR signatures of several iron sulfate species such as ferrinatrite and sideronatrite. Journal of Raman Spectroscopy, 2012, 43, pp.1265-1274. 10.1002/jrs.4041 • hal-01435266

\author{
HAL Id: hal-01435266 \\ https://hal.science/hal-01435266
}

Submitted on 18 Jan 2017

HAL is a multi-disciplinary open access archive for the deposit and dissemination of scientific research documents, whether they are published or not. The documents may come from teaching and research institutions in France or abroad, or from public or private research centers.
L'archive ouverte pluridisciplinaire HAL, est destinée au dépôt et à la diffusion de documents scientifiques de niveau recherche, publiés ou non, émanant des établissements d'enseignement et de recherche français ou étrangers, des laboratoires publics ou privés. 


\title{
Raman and FTIR spectroscopy applied to the conservation report of paleontological collections: identification of Raman and FTIR signatures of several iron sulfate species such as ferrinatrite and sideronatrite
}

\author{
Véronique Rouchon, ${ }^{a *}$ Hugues Badet, ${ }^{a}$ Oulfa Belhadj,, ${ }^{\mathrm{a}}$ Olivier Bonnerot, ${ }^{\mathrm{a}}$ \\ Bertrand Lavédrine, ${ }^{a}$ Jean-Guy Michard ${ }^{a}$ and Serge Miska ${ }^{b}$
}

Fossil materials that contain iron sulfide are well known for their instability when exposed to oxygen and humidity. This term however combines a great variety of materials showing different types of damages. Most of them consist of crystal efflorescence appearing on the surface and inside the matrix. In this work, a methodology was determined for the analysis of these damages by the use of Raman and infrared spectroscopy. The infrared and Raman signatures of a large set of iron sulfates were characterized. Specific attention was paid to sideronatrite and ferrinatrite, which are two associated sodium/ iron(III) sulfates, and their infrared and Raman bands were partially assigned. Analysis performed on a selection of 11 damaged fossils showed a great variety of degradation products: besides one case that appeared to be a synthetic resin close to polyvinylchloride acetate, which was applied with a brush on the fossil surface, all degradation products belong to the sulfate group. However, many iron-free sulfates, such as gypsum, halotrichite, epsomite, or pentahydrite were found, often in association with iron sulfates. In one case, despite the presence of iron in the matrix, no iron sulfate could be detected. This shows that the term 'pyritic fossil', commonly used by collection managers, is not appropriate as it oversimplifies the reality. A name such as 'sulfide-containing fossil' would be more suitable. Copyright @ 2012 John Wiley \& Sons, Ltd.

Supporting information is available in the on line version of this article.

Keywords: iron sulfate; fossils; degradation; sulfide; Raman spectroscopy

\section{Introduction}

Fossil materials containing iron sulfide are raising major difficulties in terms of conservation. Under reducing conditions, iron sulfide is very stable, and can be preserved in the ground for several millions of years. Under oxidizing conditions, such as moist air, it may corrode, leading to the formation of salt efflorescence, which mainly consists of iron sulfates. This efflorescence may hide the fossil print when it is formed at the surface of the object. When it is formed inside the matrix, it additionally induces mechanical stress, which leads to cracks and splitting. Paleontologists and museum conservators are largely aware of these risks, but poorly prepared to face them. The treatments that are proposed to limit the decay of sensitive fossils ${ }^{[1-7]}$ remain controversial: they are most of the time invasive, poorly documented, and systematically compromise future diagenesis studies. Anoxia appears as an alternative method to limit fossil decay, but no information is available regarding the acceptable amount of residual oxygen, and plastic bags may not be airtight enough for long term storage. ${ }^{[8,9]}$

Sensitive fossils may not be easy to identify because iron sulfide is often present at a micro (nano) scale in the matrix, which makes its detection problematic in the context of a museum. This is for instance the case with shale, which presents a uniform dark aspect but splits easily when damaged. Most of the time, these objects are rightly or wrongly called 'pyritic ${ }^{\text {[10] }}$ or 'pyritised' ${ }^{[11,12]}$ when they become fragile or show white/ yellow efflorescence. This term certainly oversimplifies the reality. Unless detailed analysis is performed to identify the chemical composition of the matrix, no one can a priori state which kind of sulfure species are involved.

Iron sulfide is often found in mines and its oxidation can cause devastating environmental damages, which motivated intensive research. ${ }^{[2]}$ Although the details of the degradation mechanism are still under investigation, ${ }^{[13]}$ most authors now agree on the fact that the decay involves the oxidation of sulfide into sulfate species. In global reactions, sulfur is oxidized, but not iron, which remains $\mathrm{Fe}^{2+}$ when released in solution. The sulfur oxidation is depicted as an electrochemical process that consists of three steps: ${ }^{[14-16]}$ first, a cathodic reaction occurs with an oxidant

\footnotetext{
* Correspondence to: Véronique Rouchon, Muséum National d'Histoire Naturelle, CRCC (Centre of Research for the Conservation of Collections), 36 rue Geoffroy Saint Hilaire, 75005 Paris, France. E-mail: rouchon@mnhn.fr

a Muséum National d'Histoire Naturelle, CRCC, 36 rue Geoffroy Saint Hilaire,
} 75005, Paris, France

b Museum National d'Histoire Naturelle, LMCM, 61 rue Buffon, 75005, Paris, France 
species (mostly $\mathrm{O}_{2}$ or $\mathrm{Fe}^{3+}$ ) at the surface of mineral grains that removes one electron; second, a transport of charge from an anodic site to the cathodic site enables the replacement of the lost electron; third, a sulfur interaction with oxygen or water leads, on the anodic site, to the formation of sulfoxy species. Despite the fact that intensive research was dedicated to iron sulfide decay, only a handful of articles deal with fossils or geological collections. ${ }^{[17,18]}$ This is probably due to the fact that these objects are poorly defined and usually present complex microstructure, which makes even more difficult the understanding of their behavior.

X-ray diffraction was used in the past ${ }^{[11,12,19]}$ to identify crystalline efflorescence appearing on damaged Pyrite $\left(\mathrm{FeS}_{2}\right)$ and Marcasite $\left(\mathrm{FeS}_{2}\right)$ specimens of the collection of Newark Museum (NJ, USA). ${ }^{[20]}$ This technique is by far the most reliable for the identification of crystalline phases, but presents several drawbacks that seriously limit its application on paleontological collections. First, a 'classic' powder diffractometer is not appropriate because it necessitates (a) a large sampling, which is incompatible with the preservation of small valuable objects and (b) the grinding of the sample, which may induce phase changes. Second, a single crystal diffractometer may be considered because it enables the analysis of a few hundreds of microns of large crystal without any grinding process, but it appears prohibitively time consuming: each analysis requires several hours, unless access to synchrotron radiation is available.

In this regard, Raman spectroscopy appears as a promising tool: it enables the in situ analysis of very small areas, of a few square microns, within a short time, which makes possible the identification of a large number of micro crystals. It also enables the mapping of larger grains to check their homogeneity. However, the analysis of shale with Raman spectrometry is limited because of fluorescence phenomena that may overcome the Raman signal. To this end, infrared techniques can be considered as a possible alternative. Raman and/or infrared spectroscopy were already used for the identification of several sulfates species. High concentrated sulfuric acid solutions were investigated, ${ }^{[21]}$ but also solid state sulfate salts, such as magnesium, ${ }^{[22]}$ aluminum, ${ }^{[23]}$ and iron ${ }^{[24-28]}$ sulfates. Recently, a great effort was devoted to the Raman characterization of mixed iron sulfates such as jarosite $\left(\mathrm{X}^{+} \mathrm{Fe}_{3}^{3+}\left(\mathrm{SO}_{4}\right)_{2}(\mathrm{OH})_{6} ; \mathrm{X}=\mathrm{K}, \mathrm{NH}_{4}, \mathrm{Na}\right.$, $\mathrm{Pb} . ..)^{[23,24,29-32]}$ copiapite $\left(\mathrm{X}^{2+} \mathrm{Fe}_{4}^{3+}\left(\mathrm{SO}_{4}\right)_{6}(\mathrm{OH})_{2} \cdot 2 \mathrm{H}_{2} \mathrm{O} ; \mathrm{X}=\mathrm{Mg}\right.$, $\mathrm{Fe}, \mathrm{Zn}, \ldots ..){ }^{[28,33,34]}$ halotrichite $\left(\mathrm{Fe}^{2+} \mathrm{Al}_{2}\left(\mathrm{SO}_{4}\right)_{4} \cdot 22 \mathrm{H}_{2} \mathrm{O}\right){ }^{[29]}$ botryogen $\left(\mathrm{MgFe}^{3+}\left(\mathrm{SO}_{4}\right)_{2}(\mathrm{OH}) \cdot 7 \mathrm{H}_{2} \mathrm{O}\right){ }^{[25]}$ etc. As a result, many sulfate species are now characterized in Raman and infrared databases. ${ }^{[35,36]}$ Although not exhaustive, these existing data show that it is feasible to distinguish most sulfate species by Raman or infrared spectroscopy.

In this work, we present an analytical methodology that combines Raman, infrared, and X-ray diffraction. It was developed for the analysis of crystal efflorescence formed on the surface of damaged fossils to establish more precisely their conservation report.

\section{Methodology}

\section{Organization of the work}

The work was organized in two parallel ways: it was first necessary to identify the Raman and Fourier transformed infrared (FTIR) signatures of different iron(II) and iron(III) sulfates. Literature and Raman/FTIR databases ${ }^{[35,36]}$ already provide some of them. These data were taken into account when they corresponded to a material claimed to be already identified by X-ray diffraction. They were additionally confirmed or completed by the analysis of a set of natural reference samples issued from the mineralogical collection of the Museum. Because these references were far from being pure products, it appeared necessary to isolate crystals that show homogeneous Raman signatures, and to perform their identification a posteriori by X-ray diffraction. The identified crystal was then finally used for FTIR measurement.

At the same time, a set of damaged paleobotanic fossils was selected and documented to identify the main degradation features (color, shape, and location of the efflorescence). Microcrystals were then sampled at the surface of the fossils. They were first analyzed by Raman spectrometry. When fluorescence was overwhelming the Raman signal, the samples were then analyzed by FTIR. In some specific cases, the fossil samples showed an 'unknown' Raman signature that had no equivalent in the literature. In these cases, homogeneous grains were selected and identified by X-ray diffraction.

\section{Fossil samples}

The present work focused on the paleobotanic collection of the National Museum of Natural History (Paris, France), which contains several severely damaged fossils. Some of these were selected for this study (see Table 1). We surprisingly observed that fossils that were excavated in the same period and preserved together in the same drawer were showing different evolutions: some of them were enduring degradation, while the others seemed in good condition. Samples of lignitized wood were additionally selected because they showed spectacular multicolored efflorescence.

A first examination showed that alterations present different aspects from one fossil to another, which led us to define four categories of damages. The first one, labeled 'type 1', refers to efflorescence of various shape and color, which is growing at the surface of the matrix, and is not correlated to the fossil shape (Fig. 1). The second category of damage, labeled 'type 2', refers to surface efflorescence following the fossil print (Fig. 2).The third category of damage, labeled 'type 3 ', refers to an efflorescence growing in the core of the matrix. This type of alteration fundamentally endangers the matrix structure but is not easy to notice at its early stage. When it is sufficiently developed, it may lead to the appearance of efflorescence in cracks (Fig. 3, lower part). In other cases, the matrix splits easily, and shows efflorescence on the hindered part of the detached flake (Fig. 3, upper part). Finally, the fourth category of damage, labeled 'type 4', corresponds to a white coating that is deposited homogeneously on the surface of the fossil. It is noticed on the fossil A only (Fig. 4).

Pictures of the fossils were taken on damaged areas that are the most representative of the whole fossil. Some of these pictures are shown in the supporting information available on the journal site. The different degradation products were sampled on these areas with tweezers and under a binocular microscope, and laid on glass slides for analysis.

\section{Raman and FTIR spectroscopy}

Micro-Raman and micro-infrared techniques were initially considered as complementary tools. Micro-infrared spectroscopy was therefore investigated in the first part of this work. It gave deceiving results: samples were highly infrared absorbing and no satisfactory signal could be obtained in reflexion and 


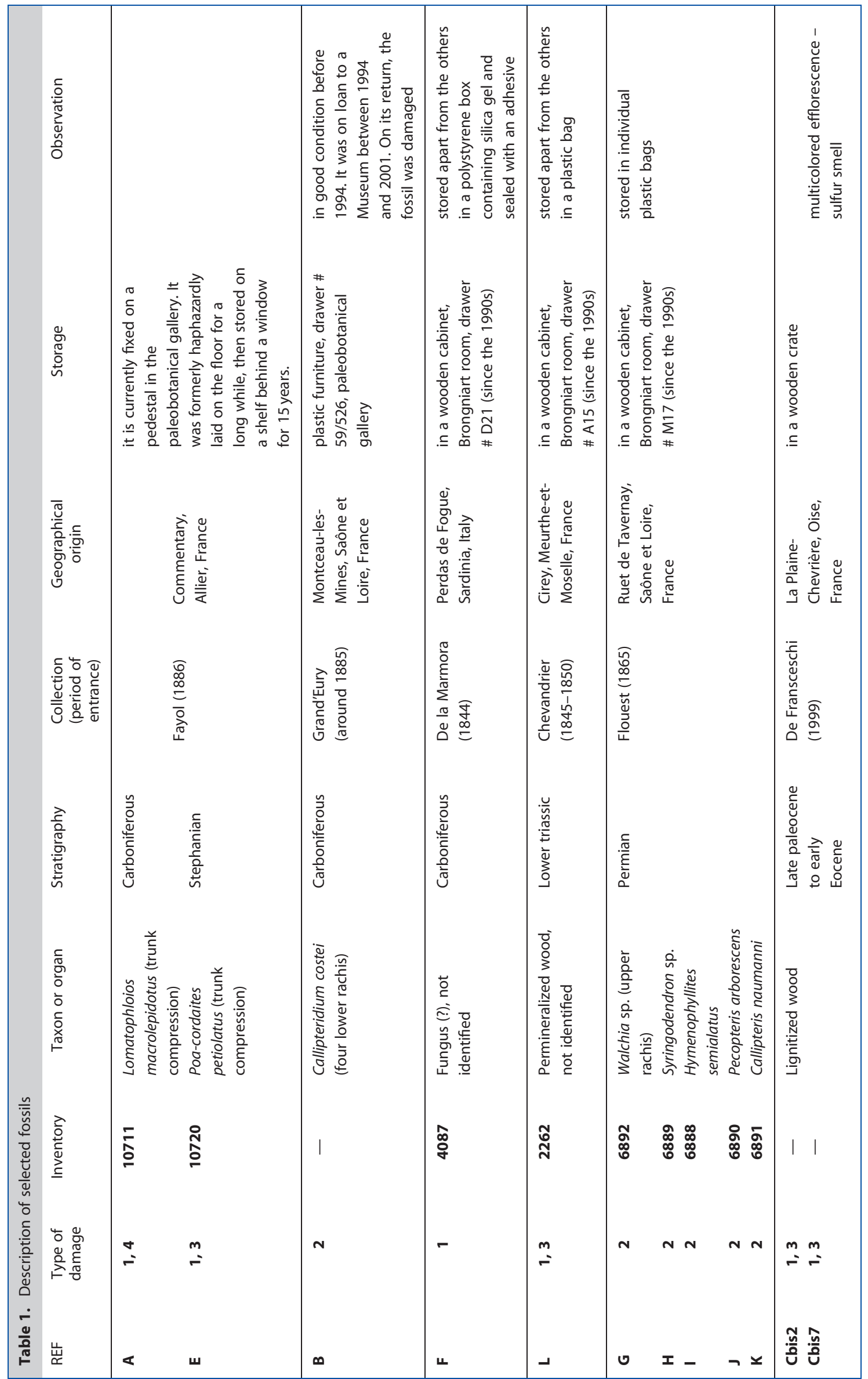




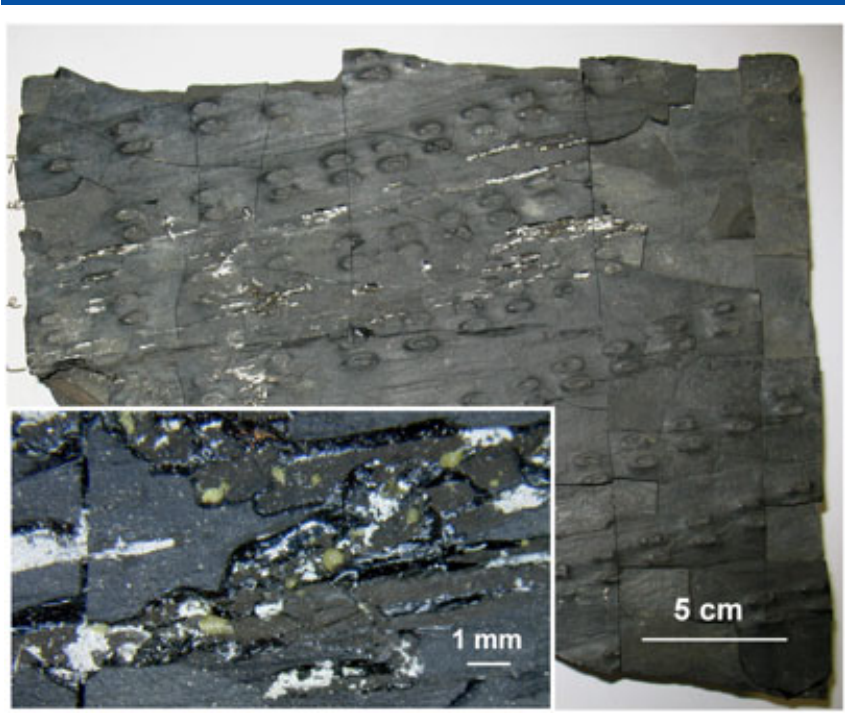

Figure 1. Illustration of type 1 damage (Fossil H).

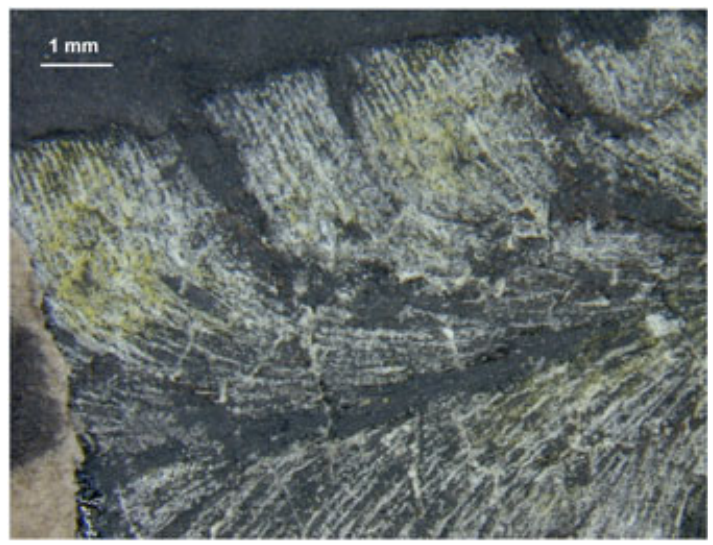

Figure 2. Illustration of type 2 damage (Fossil J).

transmission geometry; as for the micro-attenuated total reflectance (ATR) mode, it was particularly tricky to establish a satisfactory contact on small crystal grains. The use of $\mathrm{KBr}$ pellets prepared with a small quantity of crushed samples was not explored, mainly because we were not confident on the stability of hydrated sulfate phases during the sample preparation. Finally, the macro-ATR mode appeared as a satisfying technique to be implemented on our samples. Data were recorded with a conventional spectrometer (Nicolet 6700, Thermo Fisher Scientific) equipped with a diamond ATR module (SMART endurance). Analyses were conducted in a totally destructive way: a crystal grain was placed on the ATR module, then crushed within a fraction of a second and pressed against the diamond during the analysis by the use of an articulated arm. Spectra were acquired by 60 scans within the range $4000-525 \mathrm{~cm}^{-1}$ and were processed with the OMNIC software (Thermo Fisher Scientific). The fact that some phase transitions may happen during the sample crushing cannot totally be excluded, but appears to us to be very unlikely, because the infrared signatures remained similar when the operation was repeated several times on the same grain.

Macro-ATR-FTIR spectrometry presents the disadvantage of being destructive. Moreover, it complicates the analysis of mixed samples in which several components are present: the 'macro'
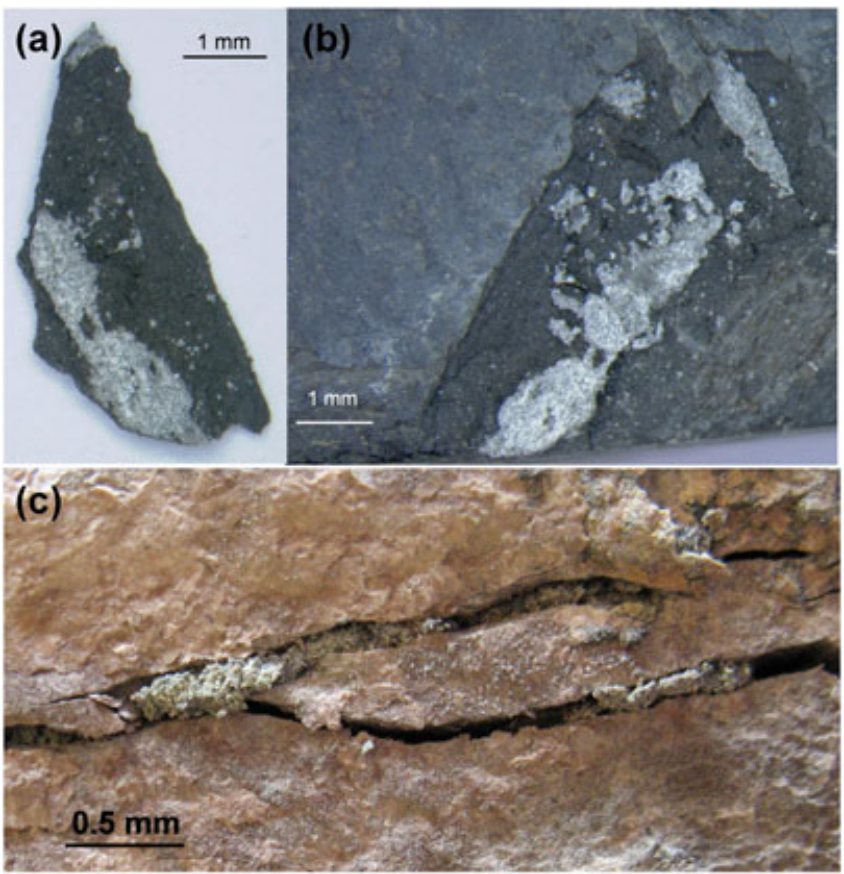

Figure 3. Illustration of type 3 damage (a) verso part of a flake detached from fossil l; (b) remaining part of the matrix of fossil l; (c) efflorescence appearing in the cracks of fossil E edge.

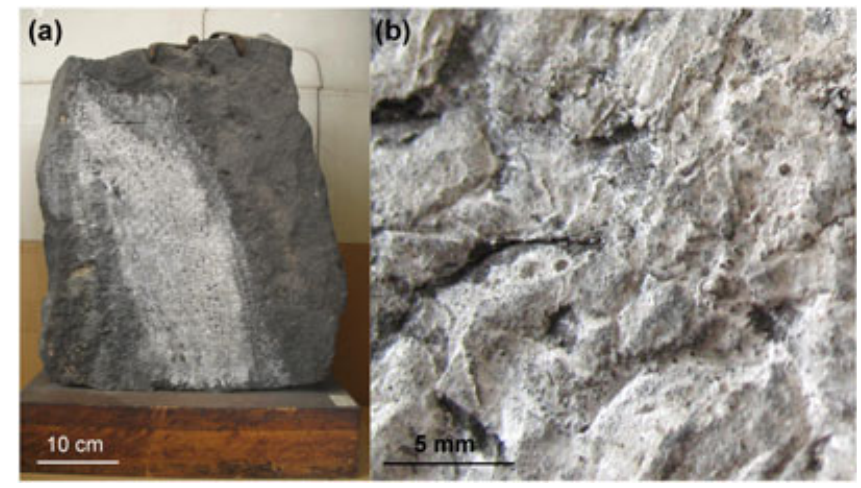

Figure 4. Illustration of type 4 damage (Fossil A): (a) overall view and (b) detail.

approach averages the signal, and minor phases become difficult to identify.

Regarding these two points, micro-Raman spectrometry certainly offers a powerful alternative because (1) it does not damage the sample provided the use of a sufficiently low beam power, (2) the analysis is performed on an area of a few square microns, which enables the distinction between several components that are mixed into a thin powder, and (3) the Raman $\mathrm{SO}_{4}$ symmetric stretching signal is very narrow and intense, which enables the identification of crystal phases, even when there is some fluorescence of the sample.

Raman spectra were acquired with a Raman microscope (inVia, Renishaw), equipped with a green $(50 \mathrm{~mW}, 532 \mathrm{~nm})$ and an infrared $(300 \mathrm{~mW}, 785 \mathrm{~nm})$ laser. Most analyses were conducted with the green laser ( $532 \mathrm{~nm}, 0.5$ to $2.5 \mathrm{~mW}$ ) and with the $50 \times$ objective. Yet the red laser $(785 \mathrm{~nm}, 1.5$ to $3 \mathrm{~mW}$ ) was also used on some samples in an attempt to reduce the fluorescence. All spectra were processed with the OMNIC software. 


\section{Complementary analysis}

X-ray diffraction measurements were undertaken to identify mineral phases that showed unknown Raman signatures. Measurements were performed on single crystals, 100 to $500 \mu \mathrm{m}$ large, with a Gandolfi $\mu \mathrm{DRX}$ device. Phase identification was performed with the International Center for Diffraction Data library. The samples were fixed at the top of a glass stick with an alcohol soluble adhesive (Klucel $\mathrm{G}^{\circledR}, 30 \mathrm{~g} \cdot \mathrm{L}^{-1}$ in $99.9 \%$ ethanol). Because this adhesive is fully reversible, the analyzed crystal could be easily recovered after analysis.

Elemental measurements were conducted with a low vacuum scanning electron microscope (JEOL, JSM-5410LV), coupled with an X-ray probe (Oxford Link Pentafet). Elemental mappings were recorded with the following experimental parameters: accelerating voltage, $20 \mathrm{kV}$; pressure, $50 \mathrm{~Pa}$; working distance, $20 \mathrm{~mm}$; aperture, 2; acquisition time, $1 \mathrm{~h}$. All data were treated with the LinkISIS software.

These measurements were undertaken on fossil matrices to determine associated elements, and on some of the efflorescence to characterize associated cations (for instance jarosite or copiapite type sulfates). Because scanning electron microscopy/ energy dispersive spectroscopy (SEM/EDS) may induce some phase changes under the beam or in low vacuum environment, it was considered as potentially destructive and systematically operated at the last step of the analytical process, i.e. after Raman, FTIR, and X-ray diffraction analysis.

\section{Results}

\section{Identification of Raman and FTIR signatures of various iron sulfates}

Raman and ATR-FTIR signatures were identified on 16 iron sulfate minerals listed in Table 2. From a general point of view, our measurements are in good agreement with the most recent literature on the topic and with the RRUFF on-line database (see Table 2) and are therefore not shown in this article. Because no published information was available regarding to the signatures of ferrinatrite and sideronatrite, it was found useful to look more closely at the specific features of these two species (see Figs 5 and 6).

Sideronatrite $\left(\mathrm{Na}_{2} \mathrm{Fe}^{3+}\left(\mathrm{SO}_{4}\right)_{2}(\mathrm{OH}) \cdot 3 \mathrm{H}_{2} \mathrm{O}\right)$ can be found in seashore or arid environments as a result of sulfide oxidation. ${ }^{[37,38]}$ It presents an order/disorder structure and reversibly dehydrates over $35^{\circ} \mathrm{C}$ into metasideronatrite. ${ }^{[39]}$ It can additionally transform into ferrinatrite $\left(\mathrm{Na}_{3} \mathrm{Fe}^{3+}\left(\mathrm{SO}_{4}\right)_{3} \cdot 3 \mathrm{H}_{2} \mathrm{O}\right)$ by contact with concentrated sulfuric acid. On the other hand, ferrinatrite can change to sideronatrite under high humidity conditions. The topological rearrangement occurring during this reversible transformation is illustrated by Scordari and Ventruti. ${ }^{[40]}$ These two phases have in common the fact that iron atoms are arranged along the $c$ axis. In the case of sideronatrite, adjacent octahedral Fe atoms are linked to each other by one hydroxyl-bridge $\left(\mathrm{OH}^{-}\right)$and two $\mathrm{SO}_{4}^{2-}$ groups. When sideronatrite changes to ferrinatrite, the hydroxyl-bridge is broken, the $\mathrm{OH}^{-}$group is removed and one additional $\mathrm{SO}_{4}^{2-}$ group is incorporated to assure an additional link between adjacent Fe atoms. The fact that ferrinatrite and sideronatrite are related phases may explain the occurrence of similar bands in the Raman (resp. infrared) spectra. For example, the sulfate symmetric stretching modes appear for both phases near 1011 and $996 \mathrm{~cm}^{-1}$.

To characterize more precisely sideronatrite and ferrinatrite's signatures, a deconvolution of Raman and infrared spectra was performed after background removal and using Lorentzian shape interpolation (Omnic software). The resulting energy of Raman lines and infrared absorption peaks are summarized in Tables 3, 4. The interpolation gave satisfactory fitting of Raman spectra, but was more delicate to implement on infrared data because the ATR mode acquisition has induced some disymmetry in the absorption bands. This point is particularly obvious on the ferrinatrite spectrum in the region $700-600 \mathrm{~cm}^{-1}$. This disymmetry may explain why a large number of absorption bands are required for the fitting

Table 2. List of iron sulfate minerals on which Raman and infrared signatures were isolated

\begin{tabular}{|c|c|c|c|}
\hline Mineral & Composition & Origin & $\begin{array}{l}\text { Other references of Raman or infrared } \\
\text { spectra }\end{array}$ \\
\hline Szomolnokite & $\mathrm{Fe}^{2+}\left(\mathrm{SO}_{4}\right) \cdot \mathrm{H}_{2} \mathrm{O}$ & Fossils & Chio et al. ${ }^{[24]}$, Majzlan et al. ${ }^{[27]}$ \\
\hline Melanterite & $\mathrm{Fe}^{2+}\left(\mathrm{SO}_{4}\right) \cdot 7 \mathrm{H}_{2} \mathrm{O}$ & Commercial reference (Aldrich) & Chio et al. ${ }^{[24]}$ \\
\hline Rozenite & $\mathrm{Fe}^{2+}\left(\mathrm{SO}_{4}\right) \cdot 4 \mathrm{H}_{2} \mathrm{O}$ & Fossils & RRUFF, $^{[35]}$ Chio et al. ${ }^{[24]}$, Majzlan et al. ${ }^{[27]}$ \\
\hline Amarantite & $\mathrm{Fe}^{3+}{ }_{2} \mathrm{O}\left(\mathrm{SO}_{4}\right)_{2} \cdot 7 \mathrm{H}_{2} \mathrm{O}$ & Mineral collection, 167.63 (Quetena, Chile) & $\operatorname{RRUFF}^{[35]}$ \\
\hline Rhomboclase & $\mathrm{HFe}^{3+}\left(\mathrm{SO}_{4}\right)_{2} \cdot 4 \mathrm{H}_{2} \mathrm{O}$ & Mineral coll. not numbered (Rio Tinto, Spain) & $\operatorname{RRUFF}^{[35]}$, Ling and Wang ${ }^{[28]}$, Majzlan et al..$^{[27]}$ \\
\hline $\begin{array}{l}\text { Coquimbite/ } \\
\text { Paracoquimbite }\end{array}$ & $\mathrm{Fe}_{2}^{3+}\left(\mathrm{SO}_{4}\right)_{3} \cdot 9 \mathrm{H}_{2} \mathrm{O}$ & Mineral coll. 170.271 (Alcapa Rossa, Chile), fossils & $\operatorname{RRUFF}^{[35]}$, Ling and Wang ${ }^{[28]}$, Majzlan et al..$^{[27]}$ \\
\hline Butlerite & $\mathrm{Fe}^{3+}\left(\mathrm{SO}_{4}\right)(\mathrm{OH}) \cdot 2 \mathrm{H}_{2} \mathrm{O}$ & Mineral coll. 167.112 (Chuquicamata, Chile) & Cejka et al. ${ }^{[26]}$ \\
\hline Metavoltine & $\begin{array}{l}\mathrm{K}_{2} \mathrm{Na}_{6} \mathrm{Fe}^{2+} \mathrm{Fe}^{3+}{ }_{6}\left(\mathrm{SO}_{4}\right) \\
{ }_{12} \mathrm{O}_{2} \cdot 18 \mathrm{H}_{2} \mathrm{O}\end{array}$ & Fossils Cbis7 & $\operatorname{RRUFF}^{[35]}$ \\
\hline Ferrinatrite & $\mathrm{Na}_{3} \mathrm{Fe}^{3+}\left(\mathrm{SO}_{4}\right)_{3} \cdot 3 \mathrm{H}_{2} \mathrm{O}$ & Fossils Cbis7 & - \\
\hline Botryogen & $\mathrm{MgFe}^{3+}\left(\mathrm{SO}_{4}\right)_{2}(\mathrm{OH}) \cdot 7 \mathrm{H}_{2} \mathrm{O}$ & Mineral coll. 171.34 (California, USA) & RRUFF $^{[35]}$, Frost et al. ${ }^{[25]}$ \\
\hline Römerite & $\mathrm{Fe}^{2+} \mathrm{Fe}_{2}^{3+}\left(\mathrm{SO}_{4}\right)_{4} \cdot 14 \mathrm{H}_{2} \mathrm{O}$ & Mineral coll. 1025R (California, USA), fossils & RRUFF $^{[35]}$, Majzlan et al. ${ }^{[27]}$, Frost et al. ${ }^{[25]}$ \\
\hline Sideronatrite & $\mathrm{Na}_{2} \mathrm{Fe}^{3+}\left(\mathrm{SO}_{4}\right)_{2}(\mathrm{OH}) \cdot 3 \mathrm{H}_{2} \mathrm{O}$ & Mineral coll. 95.360 ( Sierra Gorda, Chile) & - \\
\hline Jarosite & $\mathrm{KFe}_{3}^{3+}\left(\mathrm{SO}_{4}\right)_{2}(\mathrm{OH})_{6}$ & Mineral coll. $415 \mathrm{~J}$ (New Mexico, USA), fossils & Chio et al. ${ }^{[24]}$, Frost et al. ${ }^{[30]}$, Majzlan et al. ${ }^{[27]}$ \\
\hline Magnesiocopiapite & $\mathrm{MgFe}_{4}^{3+}\left(\mathrm{SO}_{4}\right)_{6}(\mathrm{OH})_{2} \cdot 2 \mathrm{H}_{2} \mathrm{O}$ & Mineral coll. 98.1032 (Laurium, Greece), fossils & $\operatorname{RRUFF}^{[35]}$, Frost $^{[33]}$ \\
\hline Ferricopiapite & $\begin{array}{l}\left(\mathrm{Fe}^{3+}\right)_{2 / 3} \mathrm{Fe}_{4}^{3+}\left(\mathrm{SO}_{4}\right)_{6}(\mathrm{OH})_{2} \\
2 \mathrm{H}_{2} \mathrm{O}\end{array}$ & Fossils $\mathrm{H}$ & $\operatorname{RRUFF}^{[35]}$, Frost $^{[33]}$ \\
\hline Voltaïte & $\mathrm{K}_{2} \mathrm{Fe}_{5}^{2+} \mathrm{Fe}_{3}^{3+} \mathrm{Al}\left(\mathrm{SO}_{4}\right)_{12} \cdot 18 \mathrm{H}_{2} \mathrm{O}$ & Mineral coll. $1040 \mathrm{~V}$ (Arizona, USA) & $\operatorname{RRUFF}^{[35]}$, Majzlan et al. ${ }^{[27]}$ \\
\hline
\end{tabular}



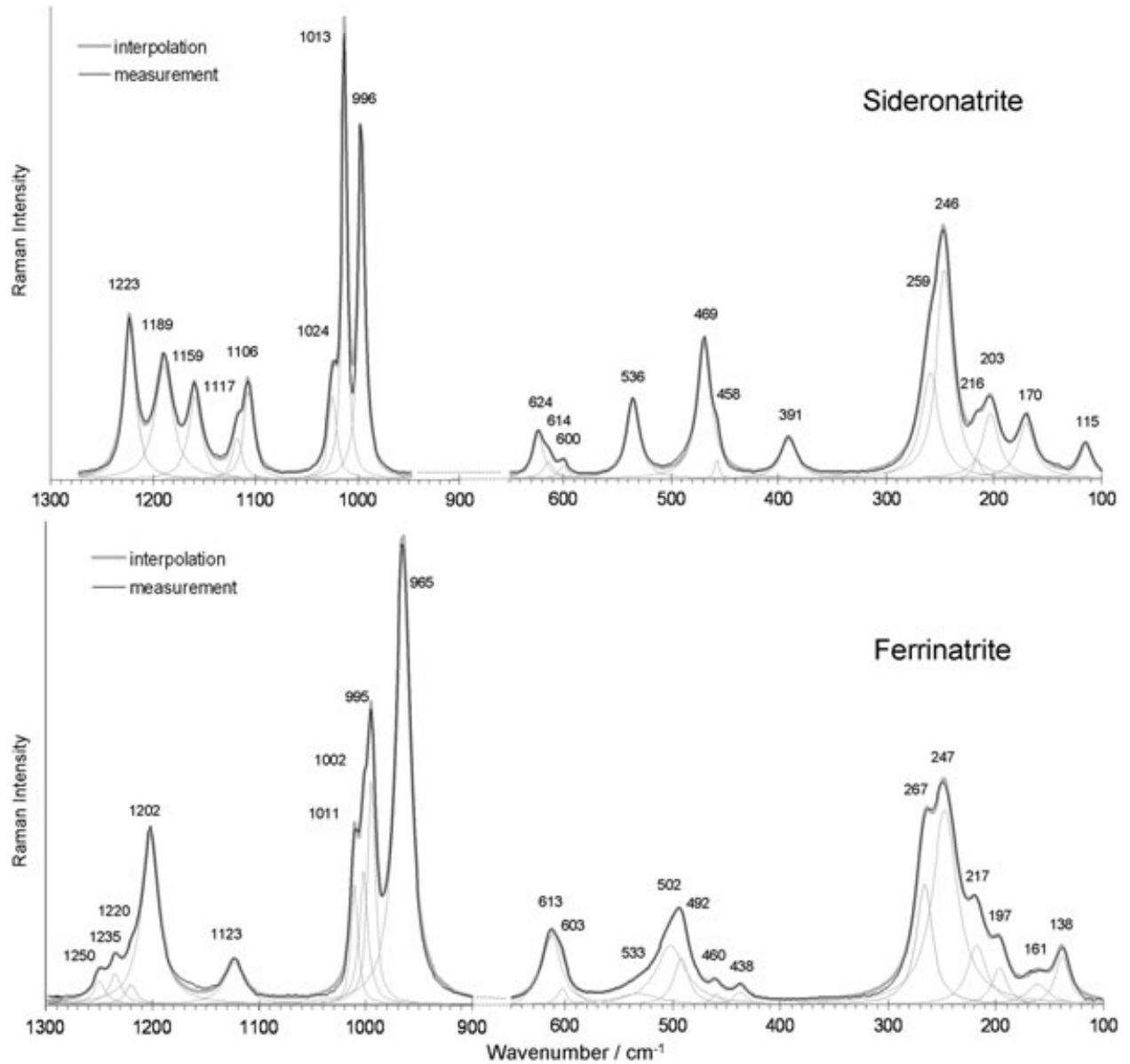

Figure 5. Raman spectra of sideronatrite and ferrinatrite. The ferrinatrite data were recorded on lignitized wood sample Cbis7 (see Table 1). The presence of sideronatrite was not highlighted on fossil samples, but on the specimen inv. 95.360 originated from Sierra Gorda, Chile and stored in the mineralogical collection of the museum. Acquisition parameters: $532 \mathrm{~nm}$, approx. $2.5 \mathrm{~mW}$ power, duration $10 \mathrm{~s} \times 10$ accumulations, $50 \times$ objective. The plots are cut between 700 and $900 \mathrm{~cm}^{-1}$ because no Raman signal was detected in this range.

of the region $800-950 \mathrm{~cm}^{-1}$. It questions the consistency of the infrared bands observed in this range, and those observed on the sideronatrite spectrum at 1088 and $1068 \mathrm{~cm}^{-1}$. These bands were also removed from Tables 3, 4.

The infrared and Raman spectra of sideronatrite and ferrinatrite are mostly based on the combination of the spectra of sulfate, lattice water, and, in the case of sideronatrite, metal complexes with hydroxyl bridges. The detailed assignment of each peak remains delicate because the regions that are specific to these different units are most of the time overlapping. A partial assignment is however possible (Tables 3,4$)$, considering the following arguments.

It is well known that free sulfates $\left(\mathrm{SO}_{4}\right)^{2-}$, of $\mathrm{T}_{\mathrm{d}}$ symmetry, exhibit four fundamental vibration modes, respectively called $v_{1}$ $\left(983 \mathrm{~cm}^{-1}\right.$, symmetric stretching $), v_{2}\left(450 \mathrm{~cm}^{-1}\right.$, symmetric bending), $v_{3}\left(1105 \mathrm{~cm}^{-1}\right.$, antisymmetric stretching) and $v_{4}\left(611 \mathrm{~cm}^{-1}\right.$, antisymmetric bending). All four modes are Raman active whereas only $v_{3}$ and $v_{4}$ are infrared active. ${ }^{[41,42]}$ The lowering of symmetry caused by coordination leads to (a) the infrared activation of $v_{1}$ and $v_{2}$ and (b) the splitting of $v_{3}$ and $v_{4}$ into several modes, depending on the resulting symmetry.

For iron sulfate compounds, the $v_{1}$ mode is expected to be infrared and Raman active. It usually gives sharp and intense Raman lines whereas corresponding infrared bands are less pronounced. The occurrence of multiple $v_{1}$ bands for sideronatrite and ferrinatrite refers to the nonequivalence of sulfate groups. The sideronatrite (resp. ferrinatrite) crystal cell displays two (resp. three) nonequivalent sulfate sites, leading to two (resp. three) $v_{1}$ bands at 1013 and $996 \mathrm{~cm}^{-1}$ (resp. 1011, 1002, and $995 \mathrm{~cm}^{-1}$ ).

Symmetric and antisymmetric bending modes $\mathrm{v}_{2}\left(\mathrm{SO}_{4}\right)$ and $v_{4}\left(\mathrm{SO}_{4}\right)$ are expected in the region $550-400 \mathrm{~cm}^{-1}$ and $550-650 \mathrm{~cm}^{-1}$. 42$]$ These two regions largely overlap with the region of lattice water librational mode $\left(600-200 \mathrm{~cm}^{-1}\right)^{[42]}$ and that of $\mathrm{Fe}-\mathrm{O}$ stretching mode $\left(900-300 \mathrm{~cm}^{-1}\right) \cdot{ }^{[41]}$ Raman lines in the region $650-400 \mathrm{~cm}^{-1}$ could also not be assigned with precision.

Many bands are observed in the region of the $v_{3}\left(\mathrm{SO}_{4}\right)$ mode $\left(1000-1300 \mathrm{~cm}^{-1}\right)$. These result from the lowering of symmetry that splits the antisymmetric stretching mode. In the case of sideronatrite, some of these wavenumbers may correspond to $\mathrm{Fe}-\mathrm{O}-\mathrm{H}$ deformation. Apart from these, all peaks appearing in that region can reasonably be attributed to $v_{3}\left(\mathrm{SO}_{4}\right)$ modes. Contrary to other types of iron sulfates, relatively high values, over $1200 \mathrm{~cm}^{-1}$, were found. This point is consistent with the fact that sulfate groups bridge adjacent $\mathrm{Fe}$ atoms and chelate $\mathrm{Na}$ atoms in a bidentate way. ${ }^{[42]}$

The most original feature of sideronatrite and ferrinatrite is related to the strong $965-968 \mathrm{~cm}^{-1}$ band, which appears on sideronatrite and ferrinatrite spectra, but was not observed on the other iron sulfates. In the case of ferrinatrite, we may consider that the $965 \mathrm{~cm}^{-1}$ wavenumber could be assigned to the $v_{1}\left(\mathrm{SO}_{4}\right)$ 

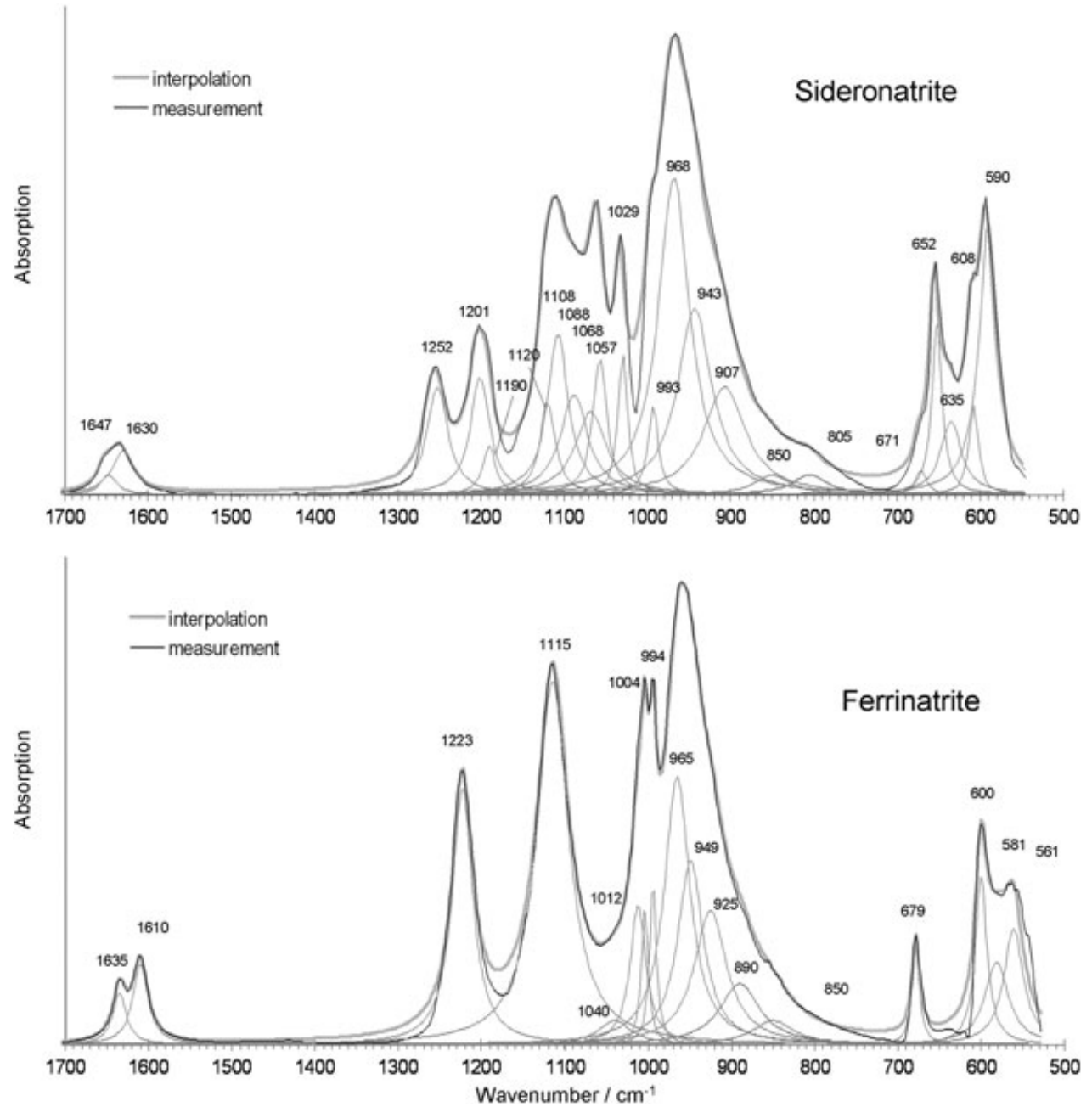

Figure 6. IRTF spectra of sideronatrite and ferrinatrite. The ferrinatrite data were recorded on lignitized wood sample Cbis7 (see Table 1). The presence of sideronatrite was not highlighted on fossil samples, but on the specimen inv. 95.360 originated from Sierra Gorda, Chile and stored in the mineralogical collection of the museum. Acquisition parameters: $60 \mathrm{scan}, 4 \mathrm{~cm}^{-1}$ resolution for sideronatrite and $2 \mathrm{~cm}^{-1}$ resolution for ferrinatrite.

\begin{tabular}{|c|c|c|}
\hline FTIR & Raman & Assignment \\
\hline 1647,1630 & 1646 & $v_{2}(\delta) \mathrm{H}_{2} \mathrm{O}$ bend \\
\hline $1252,1201,1190,1120,1108,1057,1029$ & $1223,1189,1159,1117,1106,1024$ & $v_{3}\left(\mathrm{SO}_{4}\right)$ antisym stretch and/or $\mathrm{Fe}-\mathrm{OH}$ deformation \\
\hline 993 & 996,1013 & $v_{1}\left(\mathrm{SO}_{4}\right)$ sym stretch \\
\hline 968 & - & Possibly Fe-O-S-O-Fe skeletal vibration \\
\hline $671,652,635,608,590$ & $624,614,600$ & $v_{4}\left(\mathrm{SO}_{4}\right)$ bend and/or Fe-O stretching \\
\hline- & $536,469,458$ & $v_{2}\left(\mathrm{SO}_{4}\right)$ sym bend and/or lattice water libration \\
\hline - & $391,259,246,216,203,170,115$ & $\mathrm{Fe}-\mathrm{O}$ and $\mathrm{Fe}-\mathrm{OH}$ stretch, lattice water libration \\
\hline
\end{tabular}

\begin{tabular}{|c|c|c|}
\hline FTIR & Raman & Assignment \\
\hline 1635,1610 & 1614 & $v_{2}(\delta) \mathrm{H}_{2} \mathrm{O}$ bend \\
\hline $1223,1115,1040$ & $1250,1235,1220,1202,1123$ & $v_{3}\left(\mathrm{SO}_{4}\right)$ antisym stretch \\
\hline 1012, 1004, 994 & $1011,1002,995$ & $v_{1}\left(\mathrm{SO}_{4}\right)$ sym \\
\hline 965 & 965 & Possibly Fe-O-S-O-Fe skeletal vibration \\
\hline $679,600,581,561$ & 613,603 & $v_{4}\left(\mathrm{SO}_{4}\right)$ antisym bend, Fe-O stretch \\
\hline- & $533,502,492,460,438$ & $v_{2}\left(\mathrm{SO}_{4}\right)$ sym bend, $\mathrm{Fe}-\mathrm{O}$ stretch, lattice water libration \\
\hline- & $267,247,217,197,161,138$ & Fe-O stretch, lattice water libration \\
\hline
\end{tabular}


stretching mode, taking into account the fact that some sulfates, such as munakataite $\left(\mathrm{Pb}_{2} \mathrm{Cu}_{2}\left(\mathrm{Se}^{\mathrm{IV}} \mathrm{O}_{3}\right)\left(\mathrm{SO}_{4}\right)(\mathrm{OH})_{4}\right)$, mattheddleite $\left(\mathrm{Pb}_{10}\left(\mathrm{SiO}_{4}\right)_{3}\left(\mathrm{SO}_{4}\right)_{3} \mathrm{Cl}_{2}\right)$, or spangolite $\left(\mathrm{Cu}_{6} \mathrm{Al}\left(\mathrm{SO}_{4}\right)(\mathrm{OH})_{12} \mathrm{Cl} \cdot 3 \mathrm{H}_{2} \mathrm{O}\right.$ exhibit characteristic wavenumbers in the range $960-970 \mathrm{~cm}^{-1}$. This hypothesis is however not convincing: the $965 \mathrm{~cm}^{-1}$ value is very low in comparison to the $v_{1}$ values that are measured in the other iron sulfates (above $980 \mathrm{~cm}^{-1}$ ). In addition, it can be noticed that, in the case of sideronatrite, the $965 \mathrm{~cm}^{-1}$ wavenumber is infrared active only, which a priori excludes its assignment to $v_{1}\left(\mathrm{SO}_{4}\right)$ stretching mode. The fact that the $965 \mathrm{~cm}^{-1}$ wavenumber is Raman inactive for sideronatrite, but becomes Raman active for ferrinatrite, suggests that this wavenumber corresponds to a mode in which symmetry decreases when sideronatrite is transformed into ferrinatrite. For this reason, we suggest assigning the $965 \mathrm{~cm}^{-1}$ mode to some skeletal vibration occurring via the numerous bidentate $\mathrm{Fe}-\mathrm{O}-\mathrm{S}-\mathrm{O}-\mathrm{Fe}$ bridges that are organized for both phases along the $c$ axis.

\section{The range of iron sulfates identified on damaged fossils}

Table 5 reports the different minerals identified on each fossil and shows that most efflorescence corresponds to iron sulfate species. The analysis was as exhaustive as possible to report all phases present on a significant level: several samples (at least 3) were taken on each type of efflorescence, and Raman measurements were repeated on each sample on at least ten different locations to evaluate the homogeneity of the signal. It was often observed, when the efflorescence corresponded to a thin powder of microscale grains, that several signatures were superimposing (for instance rozenite-szomolnokite, or rozenite-metavoltine-jarosite, etc.). In these cases, the acquisition was repeated on different locations until we were certain that individual signatures were recorded. This approach gave us some idea of the major and minor phases encountered.

Noticeably, ferrous sulfates were especially abundant: rozenite or zsomolnokite were present on all samples, except one (sample B contains no iron sulfate). However, contrary to observations made on the collection of Newark's museum, ${ }^{[20]}$ no melanterite was found. This is consistent with the fact that melanterite spontaneously dehydrated at low relative humidity $(\mathrm{RH})$. At the Newark museum, it was observed that the three hydrated forms of ferrous sulfate were following the season cycle: melanterite (heptahydrate) was more abundant in summer because

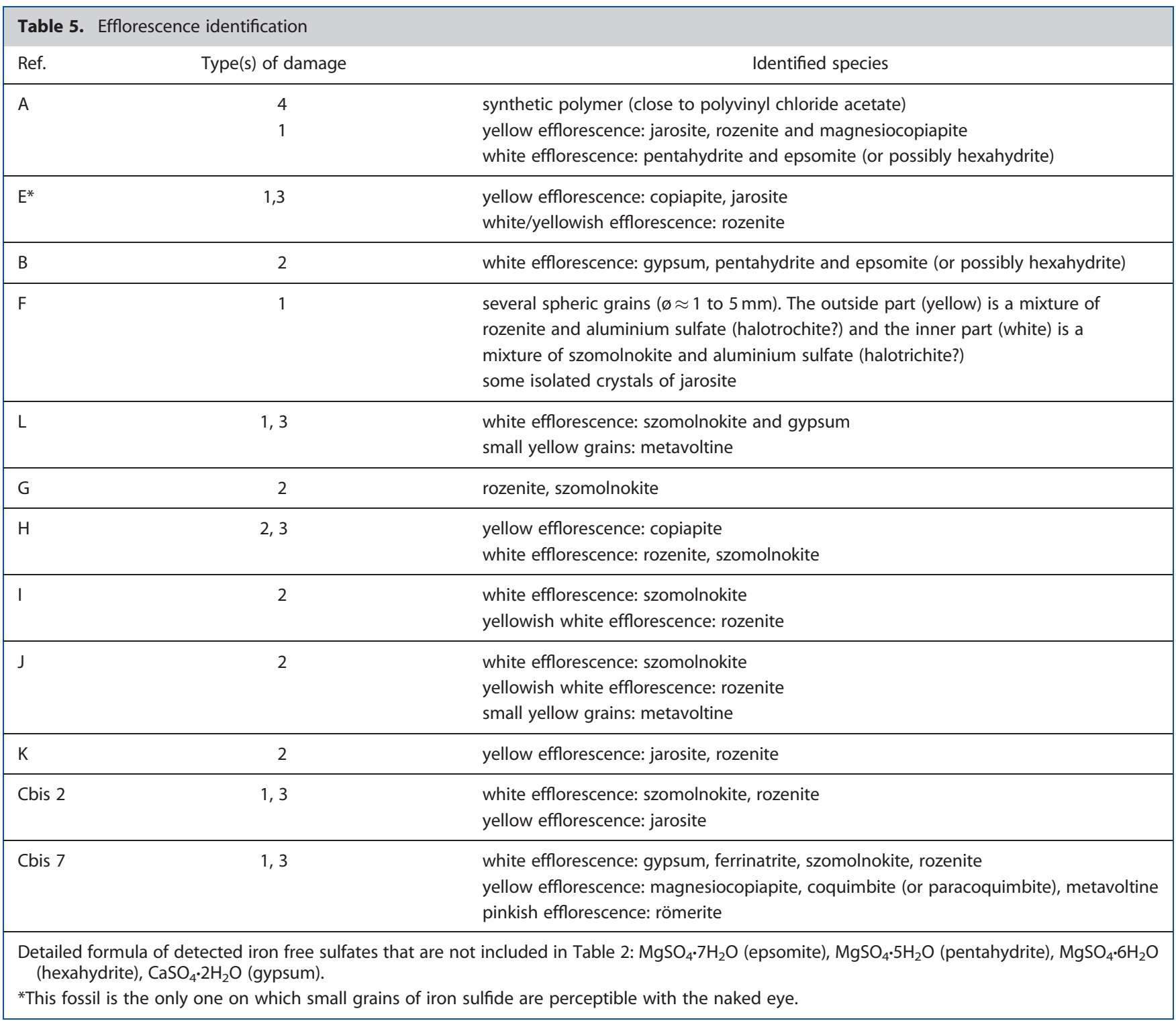


conditions were more humid (over $60 \% \mathrm{RH}$ ) and was dehydrating in winter into rozenite (tetrahydrate), and szomolnokite (monohydrate) because RH was much lower (below 40\%). In Paris, the storage conditions of the National Museum of Natural History are very dry throughout the year, which explains the absence of melanterite.

Several species of ferric sulfates were found, but they are usually much less abundant than ferrous sulfates. This preponderance of ferrous over ferric sulfate is consistent with the fact that the decay of iron sulfide first corresponds to the oxidation of sulfur, forming sulfates that react with released $\mathrm{Fe}^{2+}$.

Several explanations may account for the presence of ferric sulfates: (1) it may correspond to a minor proportion of $\mathrm{Fe}^{3+}$ $\left(\mathrm{Fe}^{3+}\right.$ is known to act as an oxidant on the cathodic site and its presence promotes iron sulfide decay) that could have been already present at the initial step of the oxidation, and have reacted with the formed sulfates; (2) it may additionally correspond to an oxidation of ferrous sulfates occurring a posteriori to iron sulfide oxidation. It is impossible to distinguish between these two scenarios without further investigations. Establishing the detailed mechanism for ferric sulfate formation is made even more complex in that ferric sulfate phases are extensively more numerous than ferrous sulfate phases, and some of them, such as the phases belonging to the copiapite and jarosite groups may include several types of other cations $\left(\mathrm{K}^{+}, \mathrm{Fe}^{2+}\right.$, etc.). Moreover, as in the case of ferrous sulfates, the stability of ferric sulfates may depend on temperature and relative humidity. Some transitions between these different phases are suggested by geological occurrence or by the analysis of museum objects: ${ }^{[20]}$ for instance, rhomboclase (resp. kornelite) often occurs with römerite (resp. coquimbite), suggesting (without proving) possible transition between these two minerals during dehydration or hydration processes. Finally, some of the ferric sulfates, such as rhomboclase, may deliquesce in high humidity conditions in an irreversible process, leading to the formation of amorphous ferric sulfate when humidity decreases.

A great part of ferric sulfates found on our samples belong to the jarosite or copiapite group. These two types of minerals are frequently found in natural environments as natural pyrite degradation by-products and often cited as significant indicators of acid mine drainage (AMD). ${ }^{[27,29,33,43-45]}$ Their occurrence on our samples suggests some similarities between AMD and the oxidative decay occurring in the context of a museum. This point is not evident at first because indoor environments are much drier than mines that are drained by water.

The occurrence of jarosite and copiapite on our samples cannot be compared with the list of ferric sulfates identified on the 14 damaged specimens of pyrite and marcasite of the collections of Newark's museum: ${ }^{[20]}$ in this list, there is no mention of copiapite. As for jarosite, it was (doubtfully) identified on one specimen only. Unless a more statistical approach is developed, it remains difficult to conclude if this difference is due to chance or if it has a meaning.

\section{Some unexpected sulfates}

Although all fossil matrices were containing iron, we cannot exclude the fact that sulfate ions get associated to other cations, such as calcium, aluminum, or magnesium. Gypsum $\left(\mathrm{CaSO}_{4} \cdot 2 \mathrm{H}_{2} \mathrm{O}\right)$ was indeed found on fossils $\mathrm{B}, \mathrm{L}$, and Cbis; aluminum sulfate was identified on fossil $F$, and pentahydrite $\left(\mathrm{MgSO}_{4} \cdot 5 \mathrm{H}_{2} \mathrm{O}\right)$, epsomite $\left(\mathrm{MgSO}_{4} \cdot 7 \mathrm{H}_{2} \mathrm{O}\right)$, or possibly hexahydrite $\left(\mathrm{MgSO}_{4} \cdot 6 \mathrm{H}_{2} \mathrm{O}\right)$ were detected on fossils $\mathrm{A}$ and $\mathrm{B}$. In most cases, these sulfate species are found together with iron sulfate. In the case of sample B however, no iron sulfate was detected on the damaged area. This is consistent with the fact that the iron that is present in the undamaged matrix is not associated with sulfur (SEM/EDS mapping, not shown). The damages observed on fossil $B$ are probably not due to the oxidation of iron sulfide, but to that of another type of sulfide (possibly magnesium or calcium sulfide).

\section{Characterization of an undesirable coating}

Very atypical damage, called 'type 4', was observed on fossil A only. It consists of a white amorphous and fluorescent product that covers a large part of the fossil (see supporting information). This coating is embedding part of a fibre, which probably comes from a paint brush. It contains a large quantity of chloride (SEM/EDS analysis), and has an infrared signature that is similar to that of polyvinyl chloride acetate, a copolymer of vinylchloride and vinyacetate (ref 182974, Aldrich) (see supporting information). This coating also refers to a synthetic polymer that was applied with a brush. It remains difficult to go further in the identification of the coating, because a large range of synthetic products have been used in conservation or preparation workshops. We however suspect the use of Mowilith, which is a polyvinylacetate, but does a priori not contain any chloride. Therefore, we suppose that the presence of chloride is due to an accidental reaction occurring on this product. Chloride-containing chemicals can possibly be found in the fossil environment. For instance, diluted solutions of hydrochloric acid are sometimes used for cleaning; chloride nitrate is often sublimated at the surface of dark fossils to create a white deposit that enhances topographic contrast and facilitates picture shot, etc. However, because the history of the fossil damage is not documented, no certitude can be put forward.

\section{Conclusion}

The first aim of this work was to define a methodology for the analysis of fossil damages. To this respect, Raman spectroscopy appeared as a powerful tool to identify sulfate efflorescence. In some cases, when the fluorescence of the matrices jeopardizes Raman analysis, macro-ATR infrared spectroscopy offers a useful alternative. The analysis of a large set of iron sulfate geological references confirmed that all kinds of iron sulfates can be distinguished by infrared and Raman techniques. These two techniques appear therefore suitable for the conservation report of paleontological collections.

Analysis performed on a selection of 11 damaged fossils showed a great variety of degradation products. In one case, the white coating had a human origin: it was identified as a synthetic resin close to polyvinylchloride acetate, which was applied with a brush. In all other cases, the degradation products were crystal efflorescence belonging to the sulfate group. A large range of iron sulfates were detected together with other types of sulfates, such as gypsum, halotrichite, epsomite, or pentahydrite. In one case, despite the presence of iron in the matrix, no iron sulfate could be detected on the damaged area. Does it mean that sulfur was not bound to iron before the degradation? Does it mean that the efflorescence result from sulfate migration from the inner to the outer part of the fossil? Is there a strong competition between iron, calcium, aluminum, magnesium to bound sulfates? To get a better insight into these points, this work will be pursued by a closer examination of damaged and non damaged matrices. The term 'pyritic fossil' appears nevertheless 
inappropriate, as it oversimplifies the reality. A name close to 'sulfide-containing fossil' would probably be more suitable.

\section{Acknowledgements}

This work was realized in partnership with the Palaeontological Collection Management Unit, Collection Department, National Museum of Natural History (Paris, France). We are grateful to our colleagues MM. Hervé Lelievre, Jean Dejax, Dario de Francesci, François Farge, Cristiano Ferraris, and Pierre-Jacques Chiappero who provided paleontological and mineralogical samples.

\section{Supporting information}

Supporting information is available in the on line version of this article.

\section{References}

[1] S. Keene, Geol. Cur. 1986, 4, 421.

[2] A. E. Rixon, Fossil animal remains. Their preparation and conservation, The Athlone Press, University of London, 1976.

[3] J. Down, E. Kaminska, J. Vertebr. Paleontol. 2005, 25, 52A.

[4] L. Cornish, Geol. Curat. 1986, 4, 451.

[5] L. Cornish, A. M. Doyle, Paleontol. 1984, 27, 421.

[6] R. Waller, in ICOM CC Proceedings, Sydney (Eds: K. Grimstad), The Getty Conservation Institute, Los Angeles, 1987, pp. 623-630.

[7] P. Godefroit, T. Leduc, CeROArt 2008, 2, http://ceroart.revues.org/464.

[8] J. Day, in ICOM CC Proceedings, (Eds: I. Verger), James \& James, The Hague, 2005, pp. 435-442.

[9] V. Carrio, S. Stevenson, in Conservation Science Proceedings, (Eds: Townsend, Eremin, Adriaens), Archetype, Edinburgh, 2002, pp. 32-38.

[10] D. Mcphail, E. Lam, A. Doyle, Conserv. 2003, 27, 107.

[11] F. M. P. Howie, Geol. Curat. Gr. Newslet. 1977, 9, 457.

[12] F. M. P. Howie, Geol. Curat. Gr. Newslet. 1977, 10, 497.

[13] R. Murphy, D. R. Strongin, Surf. Sci. Rep. 2009, 64, 1.

[14] C. Heidel, M. Tichomirowa, Chem. Geol. 2011, 281, 305.

[15] A. P. Chandra, A. R. Gerson, Surf. Sci. Rep. 2010, 65, 293.

[16] M. A. Schoonen, A. D. Harrington, R. Laffers, D. R. Strongin, Geochim. Cosmochim. Acta 2010, 74, 4971.

[17] J. D. Rimstidt, D. J. Vaughan, Geochim. Cosmochim. Acta 2003 $67,873$.

[18] D. Fellowes, P. Hagan, Rev. Conserv. 2003, 4, 26.
[19] A. Newman, Geol. Cur. 1998, 6, 363.

[20] A. M. Blount, Coll. For. 1993, 9, 1.

[21] J. M. Casas, G. Crisostomo, L. Cifuentes, Hydrometal. 2005, 80, 254.

[22] A. Wang, J. J. Freeman, B. L. Jolliff, I. M. Chou, Geochim. Cosmochim. Acta 2006, 70, 6118.

[23] C. J. Serna, C. P. Cortina, J. V. G. Ramos, Spectrochim. acta. Part A 1986, 42, 729 .

[24] C. H. Chio, S. K. Sharma, D. W. Muenow, Spectrochim. acta. Part A 2005, 61, 2428.

[25] R. L. Frost, S. J. Palmer, J. Cejka, J. Sejkora, J. Plasil, I. Jebava, E. C. Keeffe, J. Raman Spectrosc. 2011, 42, 825.

[26] J. Cejka, J. Sejkora, J. Plasil, S. Bahfenne, S. J. Palmer, R. L. Frost, Spectrochim. acta. Part A 2011; 79, 1356.

[27] J. Majzlan, C. N. Alpers, C. B. Koch, R. B. Mccleskey, S. C. B. Myneni, J. M. Neil, Chem. Geol. 2011; 284, 296.

[28] Z. C. Ling, A. L. Wang, Icarus 2010; 209, 422.

[29] R. L. Frost, M. Weier, J. Martinez-Frias, F. Rull, B. J. Reddy, Spectrochim. acta. Part A 2007; 66, 177.

[30] R. L. Frost, R. A. Wills, M. L. Weier, W. Martens, S. Mills, Spectrochim acta. Part A 2006; 63, 1.

[31] P. Makreski, G. Jovanovski, S. Dimitrovska, Vib. Spectrosc. 2005 39, 229.

[32] K. Sasaki, O. Tanaike, H. Konno, Can. Mineral. 1998, 36, 1225.

[33] R. L. Frost, J. Raman Spectrosc. 2011, 42, 1130.

[34] W. G. Kong, A. Wang, J. J. Freeman, P. Sobron, J. Raman Spectrosc. 2011, 42, 1120.

[35] R. T. Downs, 19th General Meeting of the International Mineralogical Association, Kobe, Japan, 2006, O03-13, RRUFF, http:// rruff.info/.

[36] P. Vandenabeele, H. G. M. Edwards, L. Moens, Chem. Rev. 2007; 107, 675

[37] R. Fitzpatrick, P. Shand, M. Raven, S. Mcclure, in 19th World Congress of Soil Science, Soil Solutions for Changing World Proceedings, (Eds: R. J. Gilkes, N. Prakongkep), Brisbane, International Union of Soil Sciences, published on DVD, 2010, pp. 80-83.

[38] L. J. Garvie, Mineral. Mag. 1999, 63, 757.

[39] G. Ventruti, F. Stasi, F. Scordari, Am. Miner. 2010, 95, 329.

[40] F. Scordari, G. Ventruti, Am. Miner. 2009, 94, 1679.

[41] G. Socrates, Infrared and Raman Characteristic Group Frequencies: Tables and Charts, Wiley, London, 2004.

[42] K. Nakamoto, Infrared and Raman Spectra of Inorganic and Coordination Compounds, Part B, Wiley, New Jersey, 2009.

[43] P. Sobron, A. Sanz, T. Acosta, F. Rull, Spectrochim. acta. Part A 2009, $71,1678$.

[44] L. Uzarowicz, S. Skiba, Geoderma 2011, 163, 95.

[45] T. Buckby, S. Black, M. L. Coleman, M. E. Hodson, Mineral. Mag. 2003, $67,263$. 